\title{
Electric Vehicle Implementation Guidelines
}

\author{
Chris Meetoo, Sanjay Bahadoorsingh and Chandrabhan Sharma \\ Department of Electrical and Computer Engineering \\ The University of the West Indies, St Augustine \\ Republic of Trinidad and Tobago \\ chris.meetoo.tt@ieee.org,sanjay.bahadoorsingh@sta.uwi.edu,chandrabhan.sharma@sta.uwi.edu
}

\begin{abstract}
SIDS (Small Island Developing States) are unique in their drive to reducing GHGs. Since these countries need to be self-sufficient in energy, there is a dilemma on the best way to reduce GHG while maintaining energy security. One way would be to drive the implementation of EVs for the transportation sector. However this can wreak havoc on the SIDS electrical network if not done properly. This paper reviews the possible effects of introducing EV charging on the grid. The authors have given Policy recommendations as to how EV penetration can be managed whilst maintaining the reliability and quality of the electricity grid. The authors also suggest a unique controller that can be used by the utility to limit charging time and window.
\end{abstract}

Index Terms-EV, Charging, Policy, EV Governance, GHG reduction.

\section{INTRODUCTION}

Electric vehicles are becoming popular in various markets around the world. Electric vehicle sales are expected to increase as the worlds population reduces its dependency on non- renewable fuel resources. Worldwide sales for electric vehicles have increased by $81 \%$ from 2015 to 2018 [1] and is expected to increase significantly in the future. The growth in electric vehicles has spurred significant research, development and growth in the automotive sector. This drive from conventional internal combustion engine (ICE) vehicles is set to play a key role to reduce carbon emissions linked to global warming. The electric vehicle also reduces the dependency on fossil fuels and promotes sustainable energy through the generation of electricity [2]. Also, the use of electric vehicles are becoming more prominent due to the increases in the price of fuel, for example in Trinidad and Tobago fuel subsidy decreased by $15 \%$ in 2016 [3] and fuel price is expected to gradually increase as the fuel subsidy is eventually removed. In some Caribbean countries, such as Trinidad and Tobago, Colombia, Puerto Rico, Haiti and Dominica [4] the low price of fuel may discourage the population from moving towards the use of electric vehicles as it is not economically feasible when compared to conventional vehicles, but increases in the price of fuel will promote electric vehicles as a future feasible option.

Local sectors such as Trinidad and Tobago have implemented one step towards promoting sustainable energy practices, one such implementation is the use of Compressed Natural Gas (CNG), but with the advancement of technology, electrification of transportation is inevitably. Legislative changes that allow for tax exemptions on these electric vehicles will

Digital Object Identifier (DOI):

http://dx.doi.org/10.18687/LACCEI2019.1.1.26

ISBN: 978-0-9993443-6-1 ISSN: 2414-6390 attract consumers to purchase these vehicles that will not only benefit them economically but also reduce the dependency on fossil fuels and promote a cleaner environment and sustainable development of the country. Larger regions around the world such as the United States and Europe have adopted the use of electric vehicles into various markets, however for smaller regions such as the Caribbean where electrical and business infrastructures are limited, this implementation has not been properly standardized. For such small countries, if the process of implementing the use of electric vehicles is not coordinated in an efficient manner this can lead to improvident economic decisions and improper infrastructure implementation with regard to safety and load demand from electrical utility companies. Obstacles that may arise with respect to the electrical grid include, reliability issues, increased peak loading with an associated peak generator cost, and costs to the utility in upgrading and maintaining these facilities. To fill this gap, this paper proposes a policy based frame- work that will assist governing bodies in various countries as a guide to the implementation of electrical vehicles into their system. This paper will discuss issues and details that arise from importation to electrical infrastructure that should be considered by small Caribbean countries.

A previous study [5] based on real distribution network data in Trinidad and Tobago, highlighted that a $5 \% \mathrm{EV}$ penetration can lead to feeder overloads as a result of residential AC level 2 charging. This study was classified as the worse case scenario with no diversity considerations and significant daily mileage driving, requiring daily battery charging in excess of $80 \%$ battery capacity. This confirms that the application of statistically distributed EV charging will yield greater margins for power consumption, supporting more residential electric vehicle charging. Continuing this research, applying machine learning to EV charging data can be used to optimize the utilization of existing aging distribution network infrastructure (transformers, overhead lines and cables), alleviating power system load flow congestion while delaying distribution network investments for upgrades particularly in a power system without a Time of Use (ToU) Tariff. With the exception of Barbados, Jamaica and Suriname, $75 \%$ of the countries in the Caribbean do not employ ToU tariffs [6]. At this time, there is no ToU tariff in Trinidad and Tobago.

Therefore, as these problems arises technically and nontechnically, this paper proposes a strategic framework that can alleviates both non technical and technical problems associated

$17^{\text {th }}$ LACCEI International Multi-Conference for Engineering, Education, and Technology: Industry, Innovation, And Infrastructure for Sustainable Cities and Communities, 24-26 July 2019, Jamaica. 


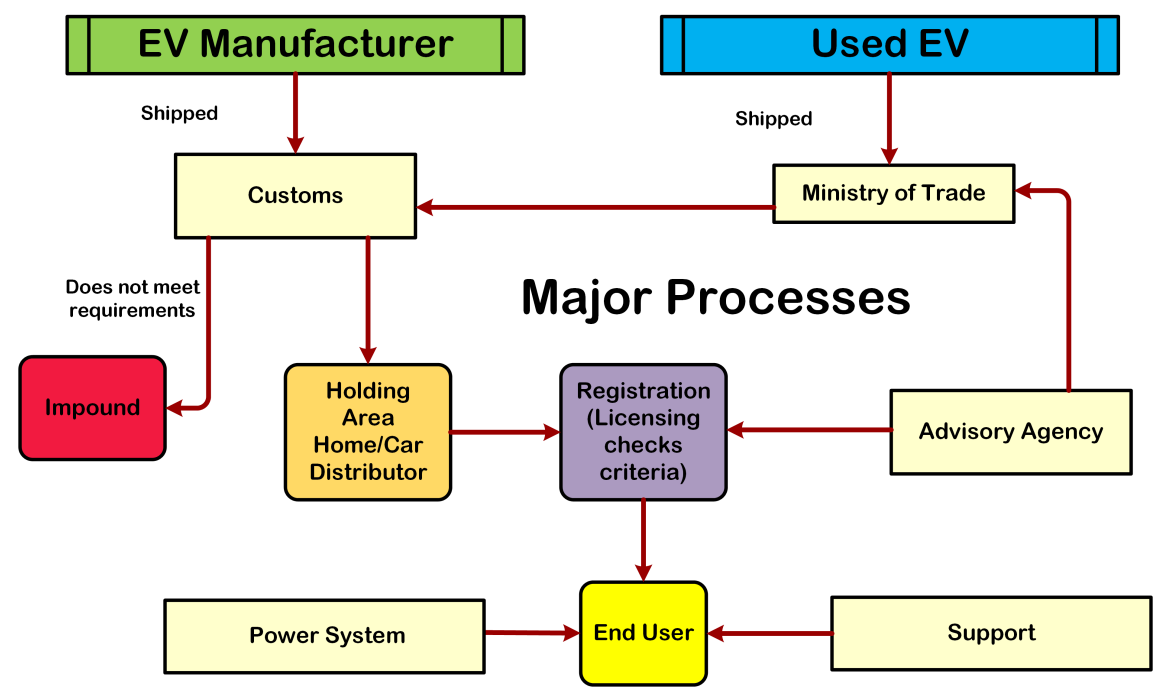

Fig. 1. Policy Framework Flow Diagram

with electric vehicle backed up with technical studies that highlights potential issues and solutions. This will allow EV implementation to be streamlined such that the EV penetration can be allowed in small proportions and eventually expand in a seamless strategic manner.

\section{POLICY CONSIDERATIONS}

Importation of EVs into small Caribbean countries require a standardized process to ensure that these vehicles firstly meet international and local standards and secondly, charging infrastructures and policies for EV waste management are properly implemented. Figure 1 shows a generalized policy framework process that can be used in small Caribbean islands to begin EV importation. At the start of this process, a vehicle may be imported directly from a firm or it may be a foreign used vehicle. If the vehicles are new, they are sent directly to the customs department. For used vehicles, the appropriate Ministry of Trade and advisory agencies need to verify extensively that these used vehicles are properly tested and meet international standards and requirements before being sent to customs. Once prior processes are checked and verified, the vehicle enters the customs process and is passed to registration and licensing. If there are issues, the vehicle should be impounded. Before the vehicle is sent to the customer various processes are to be completed. Firstly, appropriate licensing and registration fees are to be calculated and paid. Secondly, advisory agencies need to verify that proper infrastructure is present at the customer location for charging the EV according to international standards. If proper infrastructure is not present the customer shall not be able to register the vehicle until these facilities are implemented. Once the customer receives their vehicle, support should be present for the maintenance of these vehicles, these include support from the electric utility company and implementation of maintenance services such as repairs and proper disposal services for parts associated with these EVs. This policy process ensures a seamless pathway that can be followed to ensure proper integration of EVs from importation to infrastructure in a reasonable time line.

Aligning with good policy practices for electric vehicles allows for a wider target population in obtaining and using these vehicles.The use of these vehicles will heavily reduce the dependency on fossil fuels use for combustion engines and hence are aligned with NDC contributions throughout the Caribbean for reducing greenhouse gases by reducing the emissions from burning of fossil fuels and thereby promoting sustainable development. Modification of the transport sector is the simplest way to start promoting a greener environment through the use of electric vehicles. Some average savings by switching to EVs are shown in Figure 2 [7].

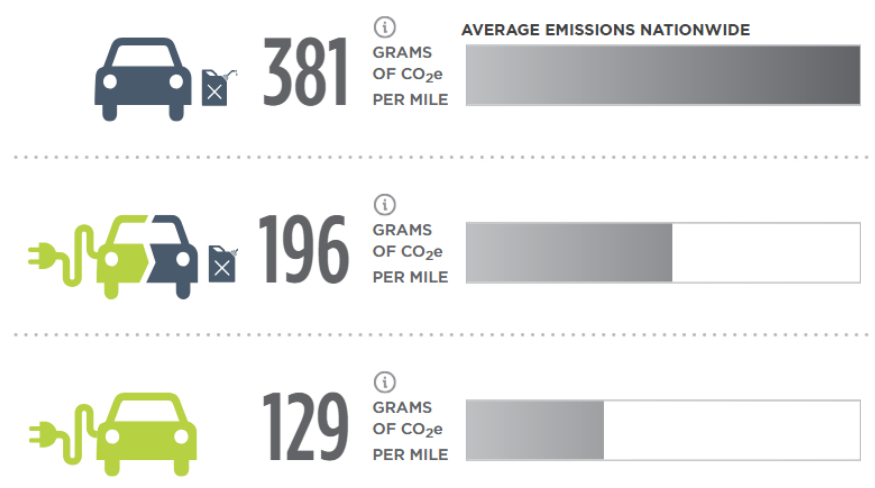

Fig. 2. Emission Savings

According to the NRDC Environmental Assessment of a Full Electric Transportation Portfolio, the Base GHG Scenario without any transportation electrification to show the effects of a grid that is already changing toward cleaner generation and a transportation fleet with improving fuel economy. When the transportation sector is electrified in the Base GHG Scenario, 2050 emissions are reduced by 48 percent from 2015 levels.

$1^{\text {th }}$ LACCEI International Multi-Conference for Engineering, Education, and Technology: Industry, Innovation, And Infrastructure for Sustainable Cities and Communities, 24-26 July 2019, Jamaica. 
In the Lower GHG Scenario, total emissions are reduced by 70 percent from 2015 levels. [8]

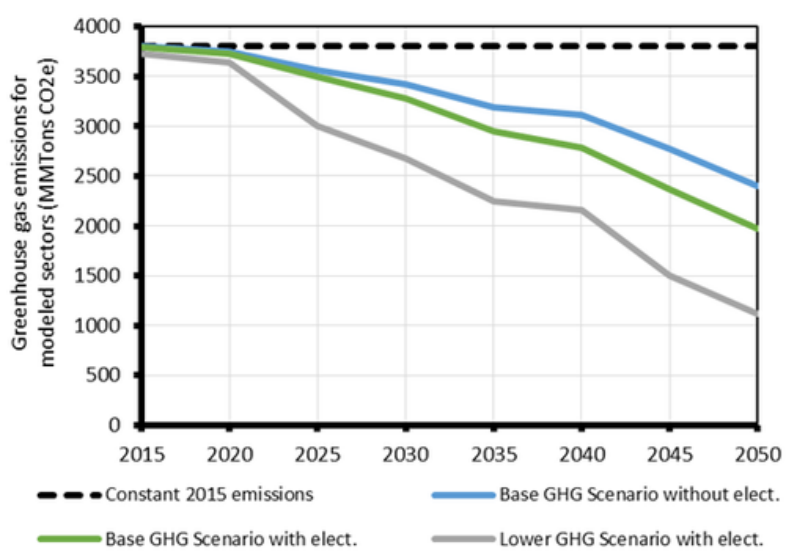

Fig. 3. Emission Reduction

Plugging in will lower carbon pollution than a comparable conventional vehicle (CV). A PEV today has 54 percent lower lifetime carbon pollution today. In 2050, the reduction could be larger, from 59 to 71 percent, as seen in Figure 4, compared to a more efficient $\mathrm{CV}$ that allows for 48 miles per gallon in real-world driving, depending on the electricity grid carbon intensity. [8]

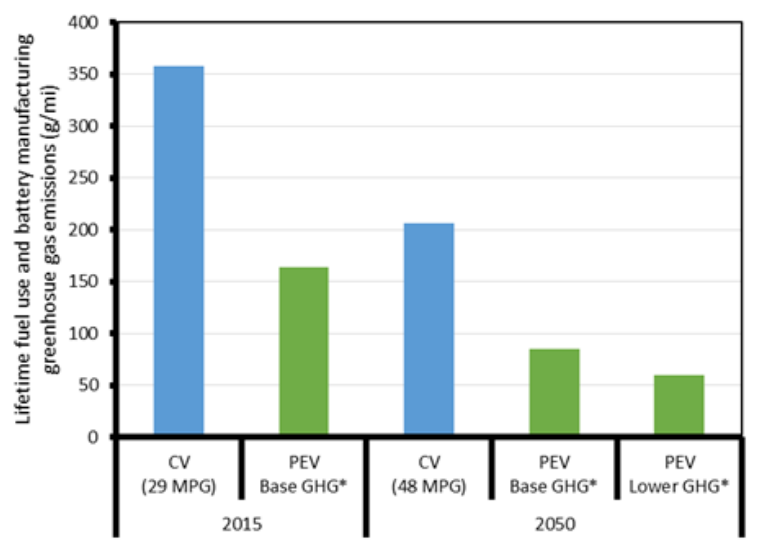

Fig. 4. Carbon Pollution

The EPRI-NRDC Environmental Assessment evaluates the air quality impact of the net pollution changes in 2030 by comparing a base, non-electrified scenario with one that includes transportation electrification. For example in the United States, electrification lowers harmful ground-level ozone, the principal component of smog, because it lowers net emissions of nitrogen oxides (NOx) and volatile organic compounds (VOC). A strong factor in these reductions was the electrification of nonroad equipment such as port cranes and cargo trucks, industrial forklifts and equipment that service aircraft when they are not flying. In most areas of the country the ozone reductions are less than 1 part per billion, but larger ozone reductions are found in areas that rely on this reduction. Many urban areas that fail to meet federal air quality standards today could see reductions of up to $3 \mathrm{ppb}$ from electrification; Los Angeles and Long Beach port areas could see reductions as high as 4 ppb. [8]

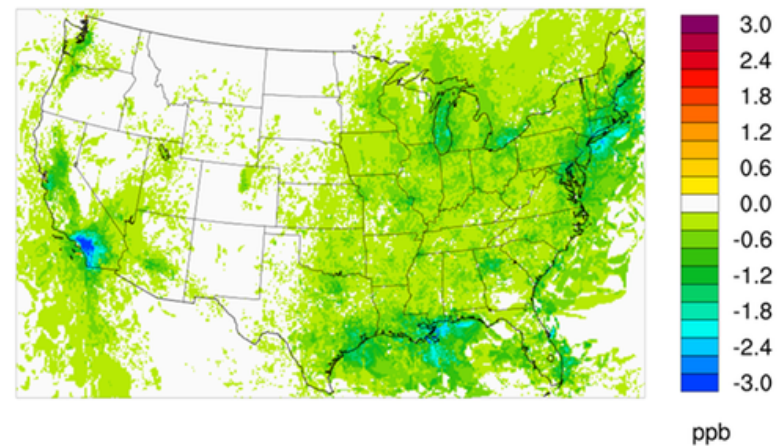

Fig. 5. Emission Savings

\section{TEChNICAL CONSIDERATIONS}

TABLE I

CONSUMER SIDE CONNECTIONS [9]

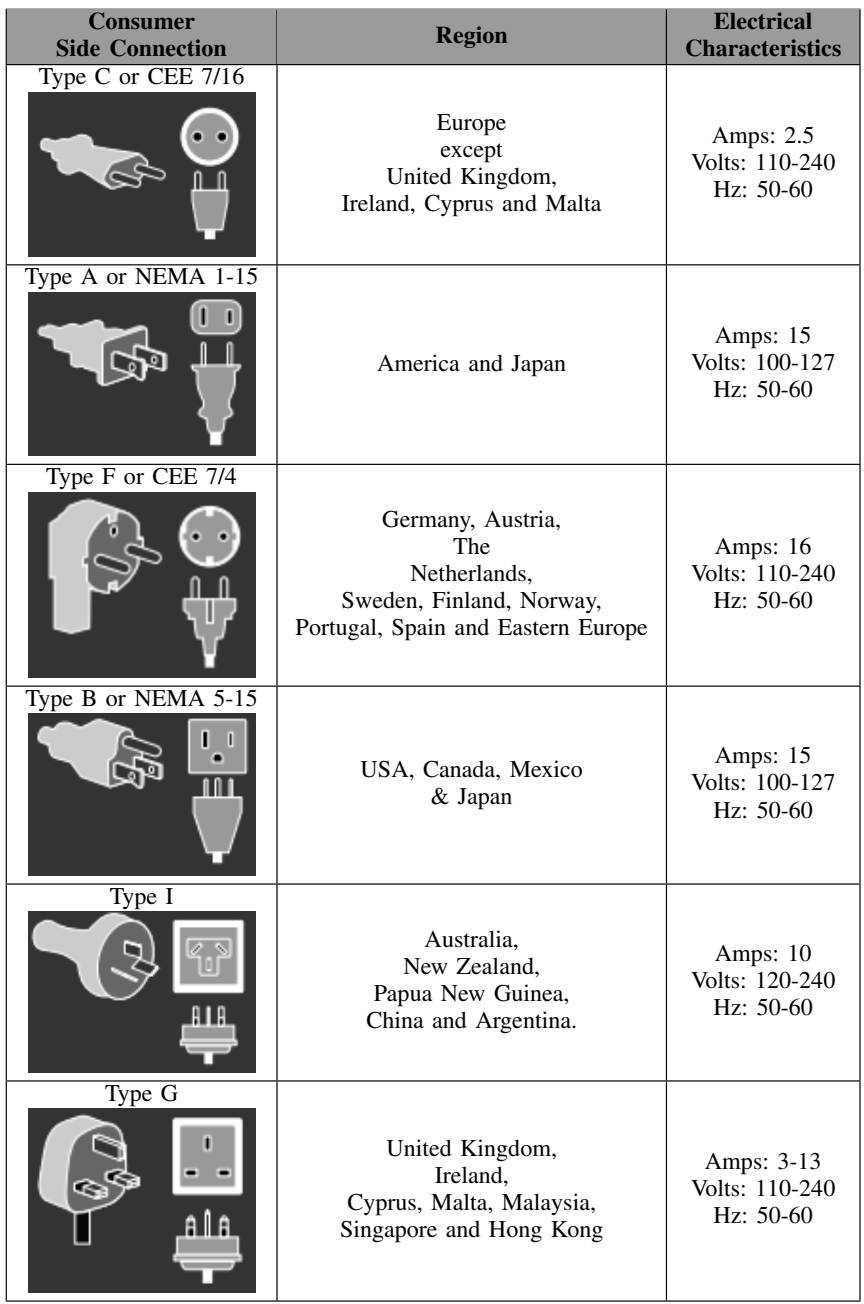


TABLE II

Vehicle Side Connections [9], [10]

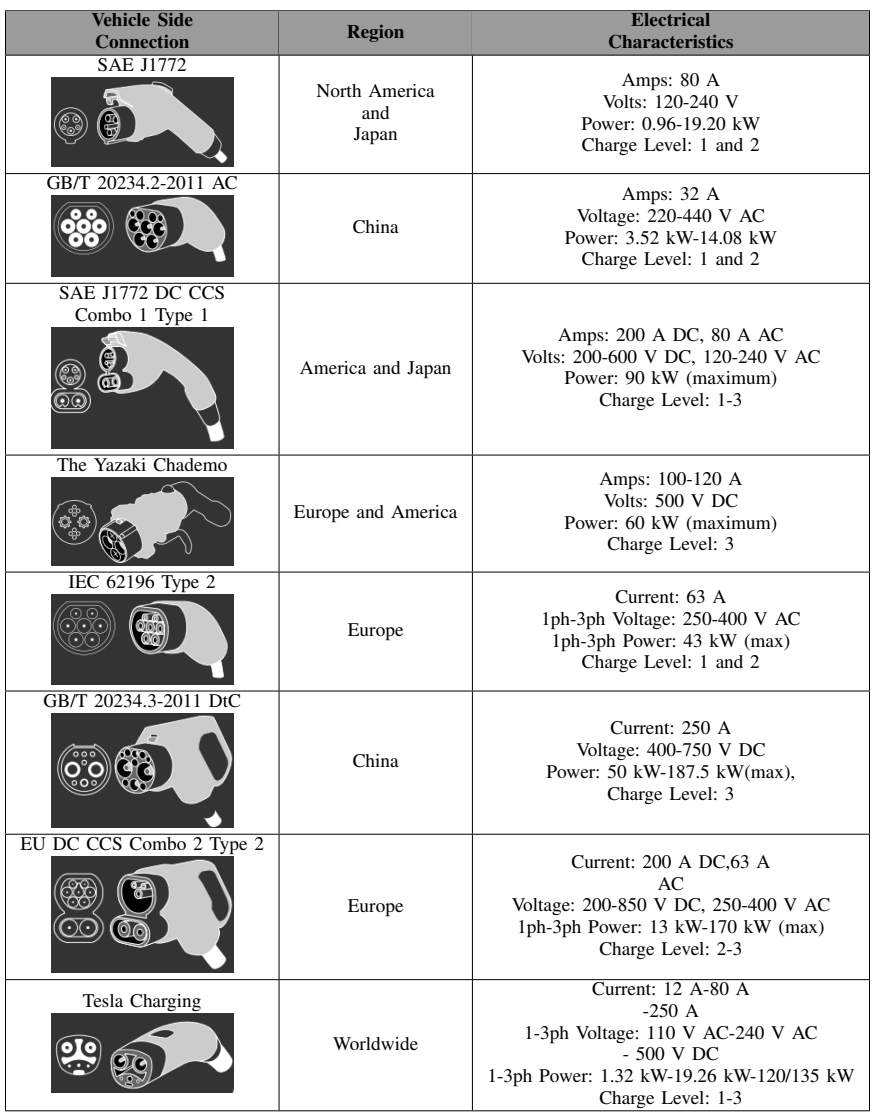

With the integration and provision of support of EVs in various Caribbean countries, standards need to be adhered with regard to electrical infrastructure and maintenance aspects of EVs. These maintenance aspects include Motor, Battery and Internal Charger systems. Table I and II show common EVSE connection both on the vehicle and home sideshow common EVSE connection both on the vehicle and home side. As the market for EVs grow, international standardization should be adopted for worldwide uniformity. The following tables list the applicable standards from ISO, UL, SAE and NFPA.

TABLE V

ELECTRIC VEHICLE INFRASTRUCTURE STANDARDS

\begin{tabular}{|c|c|}
\hline Standard & Description \\
\hline UL 2202 & Electric Vehicle (EV) Charging System Equipment \\
\hline UL 2251 & $\begin{array}{c}\text { Standard for Plugs, Receptacles, } \\
\text { and Couplers for Electric Vehicles }\end{array}$ \\
\hline UL 2594 & $\begin{array}{c}\text { Standard for Electric } \\
\text { Vehicle Supply Equipment }\end{array}$ \\
\hline SAE J2894/(1-2) & $\begin{array}{c}\text { Power Quality Requirements for } \\
\text { Plug In Vehicle Chargers - Part 1\&2 }\end{array}$ \\
\hline NFPA 70 National Electric Code & Article 625 \\
\hline
\end{tabular}

TABLE VI

ELECTRIC VEHICLE INTERNAL CHARGER AND Motor StANDARDS

\begin{tabular}{|c|c|}
\hline Standard & Description \\
\hline SAE J1772 & $\begin{array}{c}\text { Electric Vehicle and Plug in } \\
\text { Hybrid Electric Vehicle Conductive Charge Coupler }\end{array}$ \\
\hline SAE J2907 & $\begin{array}{c}\text { Power rating method for automotive } \\
\text { electric propulsion motor and power electronics subsystem }\end{array}$ \\
\hline
\end{tabular}

TABLE III

BATTERY SPECIFICATION STANDARDS

\begin{tabular}{|c|c|}
\hline Standard & Description \\
\hline ISO $12405-(1-3)$ & $\begin{array}{l}\text { Test specification for lithium-ion traction } \\
\text { battery packs and systems: Parts } 1-3\end{array}$ \\
\hline UL 2580 & Batteries for Use in Electric Vehicles \\
\hline SAE J2929 & $\begin{array}{c}\text { Electric and Hybrid Vehicle Propulsion Battery } \\
\text { System Safety Standard - } \\
\text { Lithium-based } \\
\text { Rechargeable Cells }\end{array}$ \\
\hline SAE J537 & Storage Batteries \\
\hline SAE J1495 & Test Procedure for Battery Flame Retardant Venting Systems \\
\hline SAE J1766 & $\begin{array}{l}\text { Recommended Practice for Electric and } \\
\text { Hybrid Electric Vehicle Battery Systems Crash Integrity Testing }\end{array}$ \\
\hline SAE J1797 & $\begin{array}{c}\text { Recommended Practice for } \\
\text { Packaging of Electric Vehicle Battery Modules }\end{array}$ \\
\hline SAE J2288 & Life Cycle Testing of Electric Vehicle Battery Modules \\
\hline SAE J2380 & Vibration Testing of Electric Vehicle Batteries \\
\hline SAE J2984 & $\begin{array}{c}\text { Identification of Transportation Battery } \\
\text { Systems for Recycling Recommended Practice }\end{array}$ \\
\hline SAE J3012 & Storage Batteries - Lithium-ion Type \\
\hline SAE 2974 & $\begin{array}{l}\text { Technical Information Report on } \\
\text { Automotive Battery Recycling }\end{array}$ \\
\hline
\end{tabular}

TABLE IV

Electric Vehicle SAFETy STANDARDS

\begin{tabular}{|c|c|}
\hline Standard & Description \\
\hline UL 62 & The Standard for Safety of Flexible Cords and Cables \\
\hline UL 458A & Safety of Power Converters for Electric Land Vehicles \\
\hline UL 2231-(1-2) & $\begin{array}{c}\text { Standard for Safety for Personnel Protection } \\
\text { Systems for Electric Vehicle (EV) Supply Circuits }\end{array}$ \\
\hline UL 2202 & Safety of Electric Vehicle (EV) Charging System Equipment \\
\hline UL 2251 & Standard for Safety of Plugs, Receptacles and Couplers for Electric Vehicles \\
\hline UL 2594 & Standard for Safety of Electric Vehicle Supply Equipment \\
\hline ISO 6469(1-3) & Electrically propelled road vehicles - Safety specifications \\
\hline ISO/IEC 17409 Ed. 1.0 & $\begin{array}{c}\text { Electrically propelled road vehicles Connection to an } \\
\text { external electric power supply Safety requirements }\end{array}$ \\
\hline SAE J2344 & Guidelines for Electric Vehicle Safety \\
\hline SAE J2464 & $\begin{array}{c}\text { Electric and Hybrid Electric Vehicle Rechargeable } \\
\text { Energy Storage System (RESS) Safety and Abuse Testing }\end{array}$ \\
\hline SAE J2929 & Electric and Hybrid Vehicle Propulsion Battery \\
System Safety Standard - Lithium-based Rechargeable Cells
\end{tabular}

\section{STANDARDiZATION PRocess}

SIDS should appoint appropriate bureaus that promote and encourage the development and maintenance of standards and shall further establish standards that conform to their individual needs with respect to the integration and deployment of EVs. Standards are categorized into two types, voluntary and compulsory standards. Voluntary standards are commonly used by industry "players", third party certification and by regulatory agencies. Figure 6 shows this process of standiardisaition. Compulsory standards are commonly used for the following [11]:

- Protecting the user or consumer

- Protecting public or industrial health, welfare or safety

- Protecting the environment

- Ensuring acceptable quality in products

\section{TAX EXEMPTIONS AND TARIFF CONSIDERATIONS}

The introduction of EVs have convinced countries to introduce tax exemptions for purchasing these vehicles. This endeavour promotes the change from conventional ICE to EVs and hence reduce the negative effects of harmful emissions on the environment. One such example in the Caribbean territory is Trinidad and Tobago's tax exemption policy [12]. This finance Act details tax exemptions on CNG, hybrid and EVs for both commercial and residential categories. Tax exemption is allowed on all CNG vehicles and EVs not exceeding an

$17^{\text {th }}$ LACCEI International Multi-Conference for Engineering, Education, and Technology: Industry, Innovation, And Infrastructure for Sustainable Cities and Communities, 24-26 July 2019, Jamaica. 


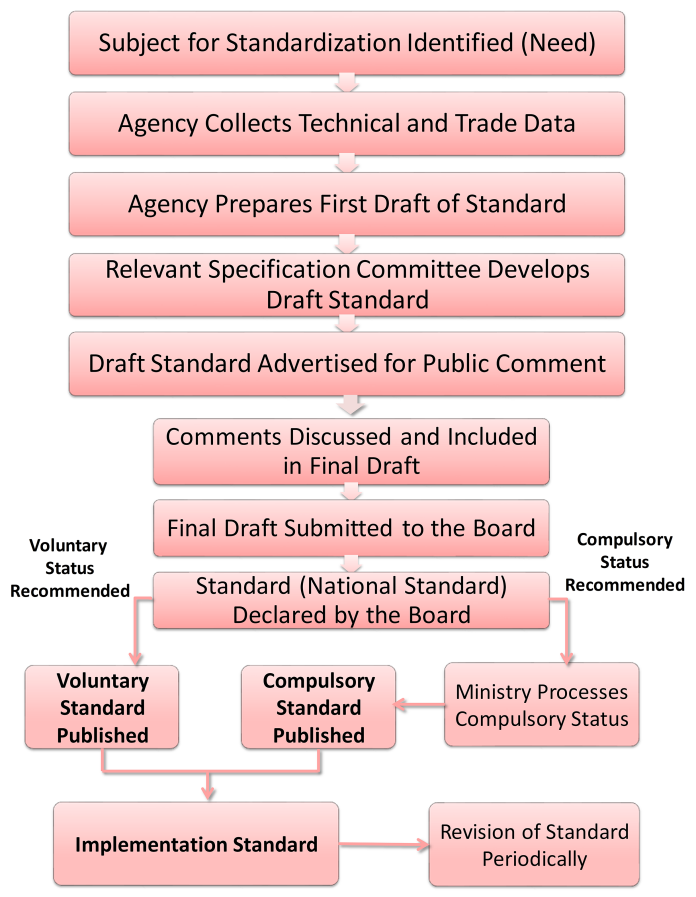

Fig. 6. Standardization Process

equivalent engine size of $159 \mathrm{~kW}$. This example can be adopted by other SIDS in the first steps for promoting EV penetration. In perspective, Trinidad and Tobago has been nourished with a fuel subsidy that is gradually being removed. With this fuel subsidy being removed and tax exemptions, EVs are becoming more favourable than the conventional ICE. Figure 7 shows the prices of both gasoline and diesel fuel in Trinidad and Tobago compared to the market value [13], [14]. It can be seen that the price of fuel is approaching the market value as the subsidy is being removed. Therefore, conventional ICE will no longer be favourable over the EV. Based on the electricity price and the price for fuel, EVs will be more economical.

Table VII shows the current electricity residential rates for Trinidad and Tobago (T\&T)

TABLE VII

TRINIDAD AND TOBAGo RESIDENTIAL ELECTRICITY TARIFF [15]

\begin{tabular}{|c|c|}
\hline Taiff Range & Rate/USD/kWh \\
\hline $1-400 \mathrm{kWh}$ & $\$ 0.039$ \\
\hline $401-1000 \mathrm{kWh}$ & $\$ 0.048$ \\
\hline$>1000 \mathrm{kWh}$ & $\$ 0.055$ \\
\hline
\end{tabular}

This is an example of the rate of electricity due to the oil and gas nature of T\&T. With tax exemptions being employed on electric vehicles and petroleum prices approaching market value. Electricity rates should be restructured by carefully considering and reviewing present tariff structures upon implementation to prevent unnecessary loss of capital.

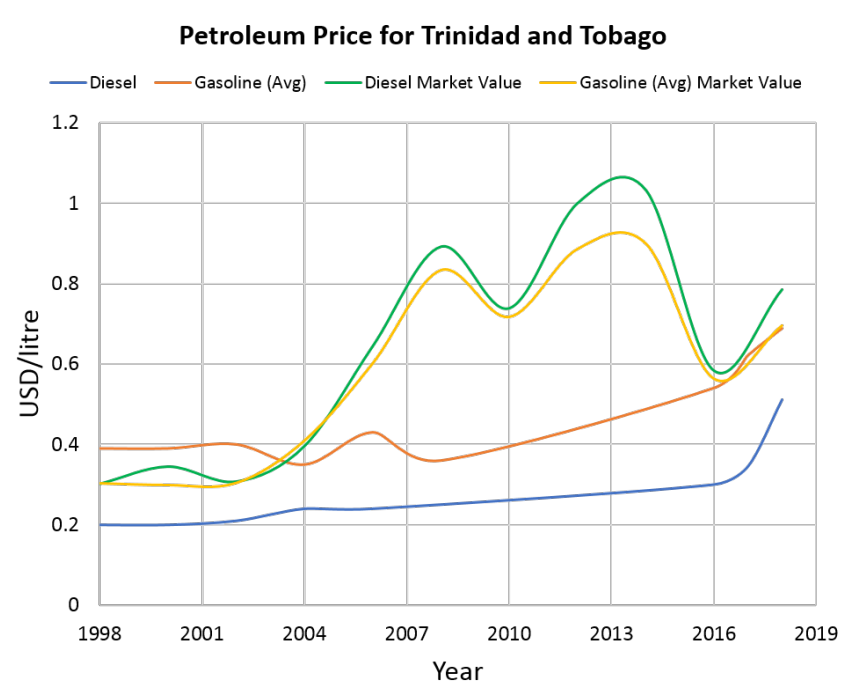

Fig. 7. Petroleum Price for Trinidad and Tobago

\section{Charging Levels and Battery Charge Times}

To date, Caribbean islands may not necessarily be equipped economically and practically to install the latest and advanced $\mathrm{EV}$ infrastructure with emerging technologies, therefore considerations need to be made with respect to the capital cost of electricity and infrastructure. In the absence of time of use tariffs, charging levels are standard and there is no financial incentives for charging at non-peak hours. However, with time of use tariffs users may opt to charge their vehicle at the lower demand levels. Regardless of time of use tariffs, considerations need to be taken with respect to infrastructure. Level 1 and 2 charging should not require any additional infrastructure for modern building as these outlets are standard. Level 3 may require the use of a three phase supply which will require additional infrastructure, due to high costs this may be more favourable to a commercial customer than residential. However, Efacec introduced a single phase DC quick charger operating on Level 2 infrastructure which may appeal to residential customers. [16]

Table VIII shows the typical charge times for the different classes of EVs at different levels of charging.

TABLE VIII

Charge Times AND BATTERY Sizing [17]

\begin{tabular}{|c|c|c|c|c|c|c|}
\hline EV Configuration & $\begin{array}{c}\text { Battery Size } \\
\text { (kWh) }\end{array}$ & $\begin{array}{c}\mathbf{1 2 0} \text { VAC } \\
\mathbf{1 5} \mathbf{a m p} \\
\mathbf{1 . 2} \mathbf{~ k W}\end{array}$ & $\begin{array}{c}\mathbf{1 2 0} \mathbf{~ V A C} \\
\mathbf{2 0} \mathbf{a m p} \\
\mathbf{1 . 6} \mathbf{~ k W}\end{array}$ & $\begin{array}{c}\mathbf{2 4 0} \mathbf{~ V A C} \\
\mathbf{4 0} \mathbf{a m p} \\
\mathbf{6 . 5} \mathbf{~ k W}\end{array}$ & $\begin{array}{c}\mathbf{4 8 0} \mathbf{~ D C} \\
\mathbf{8 5} \mathbf{a m p} \\
\mathbf{6 0} \mathbf{~ k W}\end{array}$ & Technology \\
\hline PHEV-10 & 4 & $3 \mathrm{~h} 20 \mathrm{~m}$ & $2 \mathrm{~h} 30 \mathrm{~m}$ & $35 \mathrm{~m}$ & $\mathrm{n} / \mathrm{a}$ & Toyota Prius \\
\hline PHEV-20 & 8 & $6 \mathrm{~h} 40 \mathrm{~m}$ & $5 \mathrm{~h}$ & $1 \mathrm{~h} 15 \mathrm{~m}$ & $\mathrm{n} / \mathrm{a}$ & Toyota Prius \\
\hline PHEV-40 & 16 & $13 \mathrm{~h} 20 \mathrm{~m}$ & $10 \mathrm{~h}$ & $2 \mathrm{~h} 28 \mathrm{~m}$ & $16 \mathrm{~m}$ & Chevy Volt \\
\hline BEV & 24 & $20 \mathrm{~h}$ & $15 \mathrm{~h}$ & $3 \mathrm{~h} 41 \mathrm{~m}$ & $24 \mathrm{~m}$ & Nissan Leaf \\
\hline BEV & 35 & $29 \mathrm{~h} 10 \mathrm{~m}$ & $21 \mathrm{~h} 50 \mathrm{~m}$ & $5 \mathrm{~h} 23 \mathrm{~m}$ & $35 \mathrm{~m}$ & Toyota RAV4 EV \\
\hline PHEV Bus & 50 & $\mathrm{n} / \mathrm{a}$ & $\mathrm{n} / \mathrm{a}$ & $7 \mathrm{~h} 41 \mathrm{~m}$ & $50 \mathrm{~m}$ & BYD K9 \\
\hline
\end{tabular}

$1^{\text {th }}$ LACCEI International Multi-Conference for Engineering, Education, and Technology: Industry, Innovation, And Infrastructure for Sustainable Cities and Communities, 24-26 July 2019, Jamaica. 
TABLE IX

BAttery Charge Times for Common Electric Vehicles [18]

\begin{tabular}{|c|c|c|}
\hline Model & Battery & Charge Time \\
\hline Toyota Prius & $4.4 \mathrm{kWh}$ & $3 \mathrm{~h}-115 \mathrm{VAC} 15 \mathrm{~A}$ \\
\hline PHEV & 18km All Electric Range & $1.5 \mathrm{~h}-230 \mathrm{VAC} 15 \mathrm{~A}$ \\
\hline Chevy Volt & $16 \mathrm{kWh}$ & 10h-115VAC $15 \mathrm{~A}$ \\
\hline PHEV & 64km All Electric Range & $4 \mathrm{~h}-230 \mathrm{VAC} 15 \mathrm{~A}$ \\
\hline Misubishi iMiEV & $\begin{array}{c}16 \mathrm{kWh} \\
128 \mathrm{~km} \text { range }\end{array}$ & $\begin{array}{l}\text { 13h-115VAC 15A } \\
7 \mathrm{~h}-230 \mathrm{VAC} 15 \mathrm{~A}\end{array}$ \\
\hline Smart Fortwo ED & $\begin{array}{c}16.5 \mathrm{kWh} \\
136 \mathrm{~km} \text { range }\end{array}$ & $\begin{array}{l}\text { 8h-115VAC 15A } \\
\text { 3.5h-230VAC } 15 \mathrm{~A}\end{array}$ \\
\hline BMW i3 & $\begin{array}{c}22 \mathrm{kWh} \\
130-160 \mathrm{~km} \text { range }\end{array}$ & $\begin{array}{c}\sim 4 \mathrm{~h}-230 \mathrm{~V} \text { AC } 30 \mathrm{~A} \\
50 \mathrm{~kW} \text { Supercharger }-80 \% \text { in } 30 \text { mins }\end{array}$ \\
\hline Nissan Leaf & $\begin{array}{c}30 \mathrm{kWh} \\
250 \mathrm{~km} \text { range }\end{array}$ & $\begin{array}{l}\text { 8h-230VAC } 15 \mathrm{~A} \\
\text { 4h-230VAC } 30 \mathrm{~A}\end{array}$ \\
\hline Tesla S & $70 \& 90 \mathrm{kWh}$ & $9 \mathrm{~h}-10 \mathrm{~kW}$ Charger \\
\hline Curb 2 & Up to $424 \mathrm{~km}$ range & $120 \mathrm{~kW}$ Supercharger $-80 \%$ in $30 \mathrm{mins}$ \\
\hline Fiat $500 \mathrm{e}$ & $24 \mathrm{kWh}-135 \mathrm{~km}$ range & $4 \mathrm{~h}-6.6 \mathrm{~kW}$ Charger \\
\hline Honda Fit & $20 \mathrm{kWh}-112 \mathrm{~km}$ range & $\begin{array}{c}\text { 3h-240VAC } \\
\text { 15h-120VAC }\end{array}$ \\
\hline Ford Focus & $23 \mathrm{kWh}-110 \mathrm{~km}$ range & $\begin{array}{l}\text { 5.5h-230VAC } \\
\text { 30h-120VAC }\end{array}$ \\
\hline $\begin{array}{l}\text { Mercedes Benz } \\
\text { Electric }\end{array}$ & $28 \mathrm{kWh}-136 \mathrm{~km}$ range & $\begin{array}{l}2.5 \mathrm{~h}-11 \mathrm{~kW} \\
9 \mathrm{~h}-2.3 \mathrm{~kW}\end{array}$ \\
\hline
\end{tabular}

Tables VIII-IX are all quoted in countries where the ambient temperature is lower than the ambient temperature of the Caribbean. For Caribbean countries, the temperatures will be much higher at peak times. This will result in reduced ranges over time relative to other countries as the battery life will degrade at a faster rate. However, it should be noted that Lithium-Ion batteries are best charged at higher temperatures. The Battery management system (BMS) in EVs will play an important role in charging the battery correctly based on temperature. Therefore, with the implementation of EV infrastructure, countries should ensure that personnel are well trained in the areas of maintaining and servicing the BMS in EVs.

\section{GRounding, SAFEty AND Protection}

With regard to grounding considerations for EVs, the battery isolation detection circuit is used to detect ground fault scenarios. However, the on-board EV charger works well only when the connected neutral is grounded directly to earth where the ground fault will be detected via the EVSE. In few cases the grounded neutral may have a DC offset, this DC offset can significantly damage inverter circuits present in the vehicle. Therefore, AC GFCI protection measures should be implemented to prevent this both on Level 1 and 2 charging. In cases where the vehicle is used for power export, the neutral will be directly connected to earth and the vehicle, this will cause an unintentional GFCI trip. Therefore, it is recommended not to use GFCI circuits when export power is needed, instead a supplementary grounded neural protection circuit should be implemented that works in conjunction with the GFCI circuit. This type of protection is already included in most modern vehicle EVSE. [19]

\section{LiCEnsing AND Insurance Best PRACTICE}

The basic licensing process should include the following steps [20]

1) Compliance with Vehicle Construction Requirements, exhaust (PHEV) and noise emission standards

2) Importation

3) Vehicle Inspection
4) Registration and Licensing

5) Tax (Where Applicable)

Insurance companies may want to consider the following factors [21],

1) Risk of Thermal Runaway

- If a lithium-ion battery is overheated or overcharged, it can experience a rupture and cause thermal runaway. Thermal runaway is a situation where increasing temperatures in the battery start releasing energy, which then generates heat and continues to increase the temperature of the battery

2) Risk of fire on Impact

3) Risk of fire and Injury while parked or charging

4) Risk of severe injuries in collision

- Due to the lightweight construction of EVs, the risk of injury may be higher for drivers and passengers involved in a collision. In order to extend driving distance and battery life, EVs are designed to be as light as possible

5) Risk to pedestrians

- EVs are extremely quiet, and many drivers love this feature as it makes for a very peaceful driving experience. The downside of this feature is that it may pose injury risks to pedestrians as the $\mathrm{EV}$ is mostly silent outside of the cabin as well, even when in motion

6) Aggressive driving patterns

7) Battery Disposal

With the implementation of EVs dependent on population awareness and proper infrastructure, it is difficult to ensure that owners of EVs use standardized and inspected interfaces for charging. As such, a proposed idea will be to implement a restricted policy usage for customers. This policy will entail inspecting customer premises to ensure correct infrastructure is installed for charging, this can be coupled to insurance companies to obtain insurance certificates for EVs. Also, nothing prevents the customer from charging from a noninspected or non-standard infrastructure, this practice can be deterred by stating that charging from these infrastructures will lead to voiding the warranty of the vehicles from their purchase company and also violation and termination of their insurance contract.

\section{VEHIClE TO GRID CONSIDERATIONS}

Studies indicate that vehicles are not in use for active transportation up to $95 \%$ of the time [22] and the underlying premise for $\mathrm{V} 2 \mathrm{G}$ is that during these times, the battery can be used to service electricity markets without compromising its primary transportation function. Subsets of V2G technology include vehicle-to-home ( $\mathrm{V} 2 \mathrm{H}$; when the $\mathrm{EV}$ is at a residence) or vehicle-to-building ( $\mathrm{V} 2 \mathrm{~B}$; when the $\mathrm{EV}$ is at a commercial building). In these cases, the battery power is used to supplement the building electrical load without transfer to the electrical grid. Note that this still effectively displaces the building load from the grid, which provides a load-shed 
function. Alternatively, if there is a power outage from the grid, this permits emergency backup power. Grid feedback can also be used with utilities to offer rebate to customers depending on the quantity of power they provide to the grid.

Level 1 charging, also known as "standard charging" of EVs, provides a good avenue to allow grid feedback capabilities since it is the most common method of charging. However, because level 1 charging does not allow for more than $1.6 \mathrm{~kW}$ of power transfer $\mathrm{V} 2 \mathrm{G}$ applications will be impractical using this level of charging. Level 2 charging is more promising as vehicles will be connected to the grid longer as well as allowing for significantly more power transfer (up to $19.2 \mathrm{~kW}$ ). This provides significant functional benefit for facility or grid support services. With respect to Level 3 DC charging, this provides significantly greater power transfer than Level 2 (up to $60 \mathrm{~kW}$ ), vehicles will only be connected to the grid for a short period of time for rapid charging and the user may not allow grid feedback because it can delay battery charging times. However, in the public sector where DC charging is facilitated for public transportation, at off peak times, DC grid feedback is an excellent method for large power demands. With V2G operations it is key to note that the BMS system plays an integral part in ensuring proper operation.

Communication protocols requesting the $\mathrm{V} 2 \mathrm{G}$ operation will originate at the electric utility station and deliver the request to the EVSE. The EVSE will communicate with the BMS to request the power flow. The BMS then controls the output of the inverter to respond.

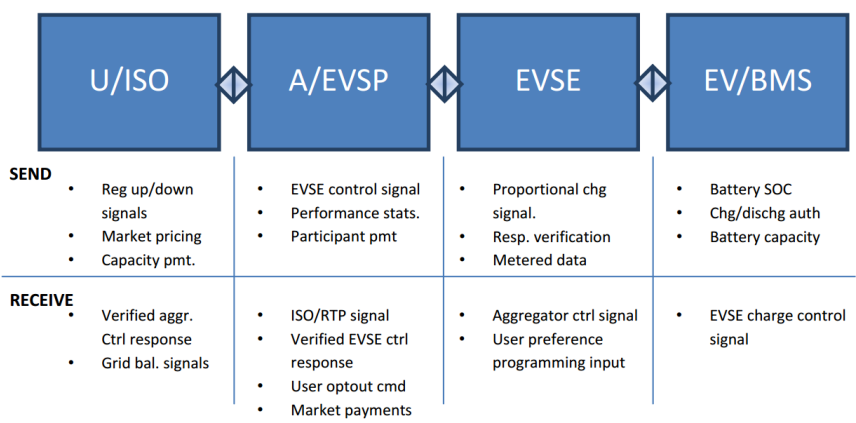

Fig. 8. V2G Modes of Operation

Some standards that should be adhered to for communication between the grid and an EV include [23]:

- ISO 15118-1-3 : Road vehicles-Vehicle to grid communication interface Part 1-3

- SAE J2293/1-2 : Energy Transfer System for Electric Vehicles: Part 1-2

- IEEE 1547 : IEEE Standard for Interconnecting Distributed Resources with Electric Power Systems

- IEEE 1675/2030/1901 - For Smart Grid Connectivity

- IEEE 1377/1701/1702/1703 - Smart Meter Standards

Solar charging can also be implemented with V2G capabilities. This is subjected to the LCOE with respect to solar charging compared to traditional prices of electricity. The benefits of solar implementation include:
1) Offset Utility Imposed Demand Charges

2) Direct Renewable to Electric Vehicle Power

3) Peak Power to Utility with battery storage

4) Battery storage in the future can be used for frequency and voltage regulation within the grid

\section{Purchasing And OWning EVs}

The utility industry should recognize that the purchase and ownership of an EV will require cooperation and coordination among several stakeholders in both private and public sectors. The major considerations are as follows: [24]

\section{A. Dealer Responsibilities}

- Relay to buyers vehicle specification, performance and charging options

- Warranty and Repair Services

- Information on Public Charging Opportunities

\section{B. Customer Responsibilities}

- Understand vehicle specification, performance and charging options

- Contact relevant authorities and contract qualified personnel for EVSE installation (if required) and understand safe charging practices

\section{Utility Responsibilities}

- Complete necessary service upgrades on distribution networks

\section{Short Term Strategic Solution for Limited INFRASTRUCTURE}

In most communities there are environmentally conscious consumers of electrical energy. This documented approach will attract and encourage all EV owners to participate in an optional coordinated EV charging scheme. The utility can consider incentivizing participation through rebates based on deferred energy consumption over the billing cycle. Figure 9 shows the system operation concept.

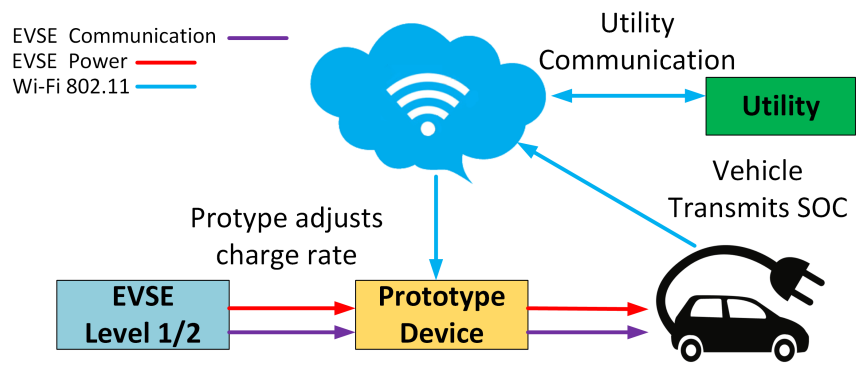

Fig. 9. System Concept

The method chosen employs the modification of pilot control signal in common Level 1/2 EV charge connectors. The choice for focus in this paper is the J1772 standard and also be applied to the IEC Type 2 (European) and the GBT connector (Chinese). The simplest and most cost 
effective (avoids upgrading utility communication systems) communication solution is to use existing WiFi (IEEE 802.11) connections. This system will inherently be a "blackbox" that is connected to the output of a J1772 charger and will provide variable constant power output to the vehicle by modifying the pilot signal duty cycle [25]. The control of the charging is facilitated by modifying the duty cycle of the pilot control signal. For a range of 6-51A this is governed by Equation 1 [25]:

$$
I=\frac{\text { DUTy CYCLE }}{0.6}
$$

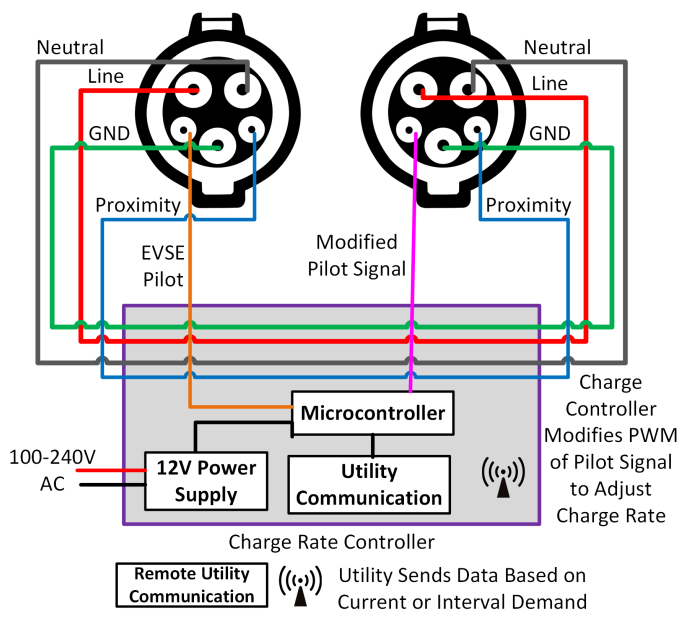

Fig. 10. Module 1 Prototype Simplified Schematic

The prototype device will allow for a coordinated charging environment controlled by the utility as shown in Figure 10 but can also be disengaged by the user based on circumstances. Module 1 is located load side of the charger. Module 2 is housed in the vehicle and will be plugged into the EV onboard diagnostic system (ODB-II) port to monitor battery state of charge (SoC) and if needed give priority charging. With clusters of EVs, algorithms can now be implemented to optimize charging with energy consumption via the use of machine learning.

\section{DynAmic COORDINATION OF EV CHARgING}

Since the time for EV charging can be remotely controlled by the utility then it would be best to spread the charging windows. This relaxes the requirement for increased power output from committed generating or committing additional units. The utility can incentivize their customers that are EV owners to provide wide window durations where and when possible to yield greater flexibility.

\section{A. Power Production and Consumption Models}

On the generation side, assume all households are served by a single power plant with a minimizing generation cost objective and during peak periods additional generating units may be committed. If the load demand increases, the duration for commitment must be financially acceptable. On the demand side, charging the EV battery is considered as a controllable load. All the other loads in a typical household are lumped and considered as uncontrollable and predictable (see [26]). It is technically beneficial to allow charging at the maximum rate and instead use scheduling to spread the load over time. Therefore, the objective is to determine when each EV should be charged at a maximum rate within the allowed window [27]. The scheduler is quite straightforward. Each time there is a request for EV charging the scheduler uses the allocated window, the SoC and the estimated time to charge the battery to determine the latest start time for charging to ensure that the battery is fully charged before the window closes. Let $\mathcal{W}$ represent the set of EVs presently waiting to be charged. For each $w \in \mathcal{W}$ let $d_{w}$ represent the deadline for starting the charging process for EV owner $w$. If the charging begins after this time then the EV owner may not be able to have a fully charged battery when the car is ready to be used. On a periodic basis the scheduler carries out the following. The scheduler chooses the EV owner with the nearest deadline to serve next (i.e., the one with the smallest $d_{w}$ ). Let $\rho$ denote the power plant utilization at that point in time, let $G$ denote the capacity of the power plant and let $p_{w}$ denote the generated power required to charge the car by $\mathrm{EV}$ owner $w$. If sufficient power is available (i.e., $\left.(1-\rho) G>p_{w}\right)$ then the the car is charged and the process is repeated. If insufficient power is available then we wait for the next scheduling instance.

\section{B. Load Monitoring and Capacity Management}

The utilization of the power plant should be near capacity since the excess generated capacity is wasted. This can be achieved by controlling the number of EVs being charged at any point in time. When utilization is low generators can be brought off-line. In order to determine when additional generators should be brought online imminent overloads need to be detected. The values $w_{d}$ can be used to detect load increases. As the number of EVs requiring charging increases or if the load due to the uncontrollable load increases then the metric

$$
L(t) \equiv \min _{w \in \mathcal{W}} w_{d}-t
$$

will decrease. In probability terms an event whereby an EV cannot be charged in time will increase. Therefore, this metric $L(t)$ will be used to determine load. Once this metric falls below some threshold a generator is brought online. For rapid load changes, the load can be quickly reduced by decreasing the charging rate of all EVs currently being charged. This will be a short term solution and should not vastly affect the overall scheduling process. The power requirements throughout this cycle is shown in Figure 11. 


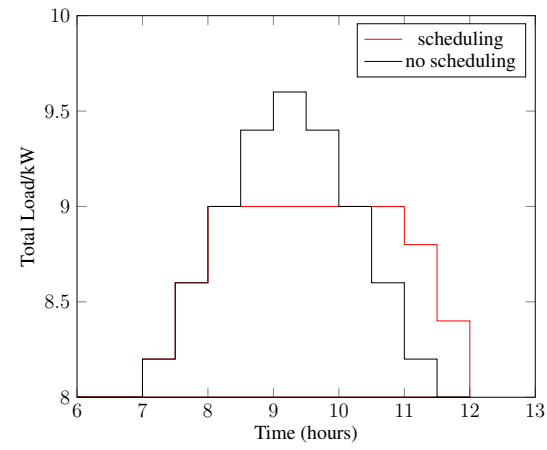

Fig. 11. Illustrative Example of Scheduler Benefit

TABLE $X$

SCHEDULER APPLICATION

\begin{tabular}{|c|c|c|c|}
\hline Start Time & EVs & Start Time & EVs \\
\hline 7:00pm & 2 & $8: 30 \mathrm{pm}$ & 4 \\
\hline $7: 30 \mathrm{pm}$ & 4 & $9: 00 \mathrm{pm}$ & 4 \\
\hline 8:00pm & 4 & $9: 30 \mathrm{pm}$ & 2 \\
\hline
\end{tabular}

Assume there is a constant uncontrollable $8 \mathrm{~kW}$ load of and EV charging requests are received with the onset of the evening residential peak load. Each EV owner has specified the EV battery charge must be complete by 8am the next morning. Assuming identical initial SoC, each EV requires $0.1 \mathrm{~kW}$ for two hours. Assuming that another generating unit must be committed if the load exceeds $9 \mathrm{~kW}$ then an additional generating unit must be brought online at $8: 30 \mathrm{pm}$ and can be taken offline at $10 \mathrm{pm}$. However, with scheduling no additional generating units are needed.

\section{CONCLUSION}

Various processes have been described to allow for a smooth EV penetration in SIDS. This starts from forming a policy framework for the importation of vehicles, development of local standards and policies, usage of controller devices to prevent overloads and machine learning algorithms for optimized scheduling. Adopting this type of model can allow for a smooth strategic transition to full EV penetration for SIDS in the future. Short and medium term solutions include using charge control techniques to ease EV penetration demand while long term planning includes infrastructure upgrades.

\section{REFERENCES}

[1] EV-Volumes.com. (2018) Global Plug-in Sales for 2016. [Online]. Available: http://www.ev-volumes.com/country/total-worldplug-in-vehicle-volumes/

[2] Alternative Fuels Data Center. (2017) Emissions from Hybrid and Plug-In Electric Vehicles. [Online]. Available: http://www.afdc.energy.gov/vehicles/electric_emissions.php

[3] The Government of the Republic of Trinidad and Tobago. (2015, Oct) Budget Statement 2016. [Online]. Available: http://finance.gov.tt/wpcontent/uploads/2015/10/Budget-Speech-2016.pdf

[4] GlobalPetrolPrices.com. (2017, May) Gasoline Prices. [Online]. Available: http://www.globalpetrolprices.com/lpg_prices/

[5] G. E. Mahadeo, S. Bahadoorsingh, and C. Sharma, "Analysis of the impact of battery electric vehicles on the low voltage network of a Caribbean island," in 2017 IEEE Transportation Electrification Conference and Expo (ITEC), Chicago, IL, June 2017, pp. 364-369.
[6] Japan International Cooperation Agency (JICA) and Shikoku Electric Power Co.Inc. (YONDEN). (2015) CARICOM Countries Renewable Energy/Energy Efficiency Data Collection Survey Final Report. [Online]. Available: http://open_jicareport.jica.go.jp/pdf/12185096.pdf

[7] Union of Concenred Scientists. (2018) How Clean is Your Electric Vehicle? [Online]. Available: https://www.ucsusa.org/cleanvehicles/electric-vehicles/ev-emissions-tool\#.XDfg71VKiUk

[8] NRDC. (2018) Study: Electric Vehicles Can Dramatically Reduce Carbon Pollution from Transportation, and Improve Air Quality. [Online]. Available: https://www.nrdc.org/experts/luke-tonachel/studyelectric-vehicles-can-dramatically-reduce-carbon-pollution

[9] EV Institude. (2017) Plug In World Map. [Online]. Available: http://www.ev-institute.com/images/media/Plug_World_map_v5.pdf

[10] Pheonix Contact. (2013) Solutions for E-Mobility. [Online]. Available: https://www.phoenixcontact.com/assets/downloads_ed/global/web _dwl_promotion/Bro_E-Mobility_Eng_low.pdf

[11] Trinidad and Tobago Bureau of Standards, "TTBS: Introduction to the Standardization Process," 2018.

[12] Trinidad and Tobago Ministry of Finance, "Act No. 15," 2017.

[13] Knoema. (2018) Trinidad and Tobago - Pump Price for Gasoline and Diesel. [Online]. Available: https://knoema.com/atlas/Trinidad-andTobago/topics/Economy/Inflation-and-Prices

[14] U.S. Energy Information Administration. (2018) Gasoline and Diesel Fuel Updates. [Online]. Available: https://www.eia.gov/petroleum/gasdiesel/

[15] Trinidad and Tobago Electricity Commission. (2018) Residential (Domestic) Rate A. [Online]. Available: https://ttec.co.tt/default/tariffs2/\#residential

[16] Efacec Electric Mobility, S.A. (2017) QC24S Quick Charging Station. [Online]. Available: http://electricmobility.efacec.com/ev-qc24s-quickcharger/

[17] The Massachusetts Department of Energy Resources. (2014, Jun) Installation Guide for Electric Vehicle Supply Equipment(EVSE). [Online]. Available: http://www.mass.gov/eea/docs/doer/clean-cities/evcharging-infrastructure-manual.pdf

[18] BatteryUniversity.com. (2016, Dec) BU-1003: Electric Vehicle (EV). [Online]. Available: http://batteryuniversity.com/learn/article/electric_vehicle_ev

[19] G. Mulchay and J. Santini, "Considerations on ground fault protection for electric vehicles," TDI Power, WhitePaper, 2012. [Online]. Available: http://www.tdipower.com/PDF/white_paper/Ground-Fault-WhitePaper.pdf

[20] Transport Department: The Government of Hong Kong Special Administrative Region. (2017, Mar) Guidelines for Importation and Registration of Pure Electric Vehicle (PEV) and Plugin Hybrid Electric Vehicle (PHEV). [Online]. Available: http://www.td.gov.hk/en/public_services/licences_and_permits/ vehicle_first_registration/guidelines_for_imp_reg_of_pev_and_phev/ index.html

[21] C. K. Panasiewicz. (2017) Electric Vehicles And The Unique Risks Insurers Need To Consider. [Online]. Available: http://www.origin-andcause.com/media/SEVEN\%20UNFAMILAR\%20RISKS_02_Rev_03.pdf

[22] A. Briones, J. Francfort, P. Heitmann, M. Schey, S. Schey, and J. Smart, "Vehicle-to-Grid (V2G) Power Flow Regulations and Building Codes Review by the AVTA," Idaho National Laboratory, Tech. Rep., 2012. [Online]. Available: https://energy.gov/sites/prod/files/2014/02/f8/v2g_power_flow_rpt.pdf

[23] IEEE Standards Association. (2012, Jan) Enabling Consumer Connectivity Through Consensus Building. [Online]. Available: https://beyondstandards.ieee.org/networking/consensus-building/

[24] L. Dickerman and J. Harrison, "A new car, a new grid," IEEE Power and Energy Magazine, vol. 8, no. 2, pp. 55-61, March 2010.

[25] SAE Electric Vehicle and Plug in Hybrid Electric Vehicle Conductive Charge Coupler, SAE International Std., 2017.

[26] S. Hosein and P. Hosein, "Load forecasting using deep neural networks," in 2017 IEEE Power Energy Society Innovative Smart Grid Technologies Conference (ISGT), April 2017, pp. 1-5.

[27] E. Apostolaki-Iosifidou, P. Codani, and W. Kempton, "Measurement of power loss during electric vehicle charging and discharging," Energy, vol. 127, pp. 730 - 742, 2017. [Online]. Available: http://www.sciencedirect.com/science/article/pii/S0360544217303730 